\title{
Population density of free-living nematodes and their relationships with some soil physicochemical properties in forest and agriculture soils of Gapa Valley Chalt, Gilgit, Pakistan
}

Muhammad Shoaib ${ }^{1}$, Sameena Mumtaz ${ }^{1}$, Aqleem Abbas ${ }^{2 *}$, Farida Begum $^{3}$ and Babar Hussain ${ }^{4}$

1. Department of Biological Sciences Karakoram International University, Gilgit Baltistan-Pakistan

2. State Key Laboratory of Agricultural Microbiology and Provincial Key Laboratory of Plant Pathology of Hubei Province, College of Plant Science and Technology, Huazhong Agricultural University, Wuhan 430070, Hubei, PR-China

3. Department of Environmental Sciences Karakoram International University, Gilgit Baltistan-Pakistan

4. Institute of Agricultural Resources and Regional Planning, Chinese Academy of Agricultural Sciences, Beijing 100081-China

*Corresponding author's email: aqlpath@gmail.com

Citation

Muhammad Shoaib, Sameena Mumtaz, Aqleem Abbas, Farida Begum and Babar Hussain. Population density of free-living nematodes and their relationships with some soil physicochemical properties in forest and agriculture soils of Gapa Valley Chalt, Gilgit, Pakistan. Pure and Applied Biology. Vol. 10, Issue 1, pp465-473. http://dx.doi.org/10.19045/bspab.2021.100050

\begin{tabular}{|c|c|c|c|}
\hline Received: 02/07/2020 & Revised: 26/09/2020 & Accepted: 05/10/2020 & Online First: $24 / 10 / 2020$ \\
\hline
\end{tabular}

\section{Abstract}

The present study was conducted in Gapa Valley, Chalt, Gilgit-Baltistan, Pakistan to check the relationship of free-living nematodes in association with soil physicochemical properties. Soil samples from five random sites of pine and potato fields were collected. From each site three composite soil samples were collected, one to determine soil bulk density while two to determine the physicochemical parameters and diversity of free-living nematodes. The nematodes were extracted using modified Baermann's funnel method and the count showed that the population density of free-living nematodes was generally lower in the pine forest than potato fields. About 156 nematodes belonging to 15 families were recorded in the potato field and 39 nematodes belong to 18 families were recorded in pine forests. Moreover, remarkable differences in physiochemical properties viz., SMC (Soil moisture Content), EC (Electrical conductivity), $\mathrm{pH}$, temperature, soil texture, BD (Bulk density), was found between the pine forest and potato fields. The soil of pine forest was highly acidic with $\mathrm{pH}$ 5.90 while the soil of potato fields was near to neutral with $\mathrm{pH}$ 6.53. Moreover, temperature, EC and SMC of potato fields were higher than that of pine forests. Additionally, the soil texture of potato fields was silty and sandy loamy soil whereas the soil texture of pine forest was silty but with a high amount of silt content. Finally, Pearson's correlation showed significant positive and negative correlations between some of the soil physicochemical parameters and nematode population.

Keywords: Free-living nematodes; Physiochemical; Population density; Correlation 


\section{Introduction}

Gilgit-Baltistan (GB) is the mountainous region of Pakistan. It contains fifty highest peaks and three world's longest glaciers and is one of the spectacular regions of the world. The livelihood of the local people depends on the soil resources of the region. Soil is a mixture of weathered rocks in combination with minerals and organic materials. Organic materials of soil are from the dead flora and fauna. The soil-based on the organic and mineral contents are divided into zones. The uppermost zone is known as "A horizon" and this layer is known to be a biologically most active layer because it mostly consists of organic materials. The next layer is "B horizon" where most of the physical and chemical reactions take place and the actual reshaping of any soil type depends on this horizon. Following B horizon there is " $\mathrm{C}$ horizon" which is from the soils above as A and B horizon and it's inactive with no physical or chemical reactions taking place [1-3]. While Soil texture depends on the different proportional combination of sand, silt and clay. Similarly, soil colour depends on the quantity of mineral contents of the soil, for instance, the colour of soil is dark black or brown and it is due to the presence of the excess of organic material. They may be dark, orange-brown or yellowish-brown depending on the amount of iron content in that soil. Hence, the soil formation of any area depends on the climate, landscape, organisms, parent material, and time. These five factors are involved in making any type of soil [3-5]. Furthermore, people use soil to cultivate food. Soil also serves as filtering media for water hence soil is the naturally existing place for all living things that supports and nourishes every organism. Among these living things, the diversity and population density of the free-living nematodes in this region is poorly understood. The free-living soil nematodes are contributing a significant role in the soil structure because they utilize the soil pores and depend on the water around the soil particles, soil types, amount of organic matter and vegetation types of a particular area [6-8]. The freeliving nematodes have low structural diversity but include a variety of species. Their anatomy is like a tube inside the tube with an unsegmented body. They have a different mode of feedings groups while reproductively they are varied as hermaphrodites and some behaving as males all these indicate the massive diversity and distribution of nematodes [911]. These free-living nematodes are good bioindicators because of the rapid life cycle they can be affected by different environmental factors of soils like climate, $\mathrm{pH}$, moisture, temperature etc. Moreover, they are omnivores, predatory nematodes, fungal feeders, bacterial feeders and their different proportions shows the normal or abnormal status of soil [10-12]. Nematodes are present in different trophic levels in food web they are capable of doing decomposition, nutrient cycling and they are involved in the growth of various plants [9,11]. Nematodes may cause zoonotic diseases in humans for example, Dirofilariarepens causes dirofilariasis. Similarly, in plants, they are responsible for causing severe diseases. Further, they are easily transmitted by mosquitoes, dogs, cats, wolfs and through human faeces [13]. Free-living nematodes are found almost everywhere on earth and the population density of these nematodes in a particular area can be checked by researching that area while associating their population density to the climatic factors, vegetation, soil types and physicochemical properties of the soil where they are residing [14]. Scope of studying climatic factors, vegetation and soil types are beyond this research. However, keeping in view, the importance of free-living nematodes of these harsh environmental regions, present study aimed to investigate population density of free-living nematodes in the pine forests and potato fields in relation to physicochemical properties of soil. 


\section{Materials and Methods}

\section{Sites description and experimental design}

Soil samples were obtained from five sites within the GAPA valley, of the District Nagar, Gilgit Baltistan that encompass an elevation gradient ranging from 3000 to $3500 \mathrm{~m}$ above sea level. The valley is covered by mountains which are stocked with pine trees naturally; however, in the less elevated grounds potatoes are extensively grown. As the area is mountainous, and soil in the most of sites is rocky, therefore the capability to obtain soil samples using cork borers within canopies of pine trees, become difficult. Soil therefore was collected using local spades. However, the soil from the potato fields was soft enough to obtain soil samples with cork borers. Plants remain from the surface of the soil were removed, and soil was collected from the depth 5-10 $\mathrm{cm}$. Within each site of GAPA valley, five fields of potatoes and five sites of the pine forests were selected for soil sampling. From each field of potato and each site of the pine forest, three subsoil samples were collected. One subsample to measure bulk density whereas two subsamples were to determine the population density of freeliving nematodes and soil physicochemical properties including soil texture, soil temperature, soil $\mathrm{pH}$, soil EC (Electrical conductivity) and soil moisture contents (SMC). For each subsample, approximately $0.5 \mathrm{~kg}$ of soil was collected. At each sampling site, altitude, coordinates were recorded by GPS and temperature was also recorded. Moreover, the information regarding agricultural practices and irrigation timings of potato fields from the owners were also gathered. The soil was shifted to the nearby research station and sieved to remove rocks, plant debris and other litters. The soil was then transferred to plastic bags and shifted to the Karakorum International University (KIU), Gilgit and stored at $4{ }^{\circ} \mathrm{C}$ until analyzed.

\section{Nematode extraction and counting}

Nematodes were extracted using a modified Baermann's funnel technique from 100-gram soil over 72 hours (Fig. 1). The nematodes were extracted after 24 hours for three days [15]. Nematodes were preserved in 5\% formalin solution. A compound light microscope was used to count the total number of nematodes in each sample. Nematodes (100 per sample) were identified to the family level under $40 \mathrm{x}$ and $100 \mathrm{x}$ magnification of the microscope and assigned to trophic groups i.e. fungivores, bacterivores, plant parasites, omnivores and predators using the keys of [16].

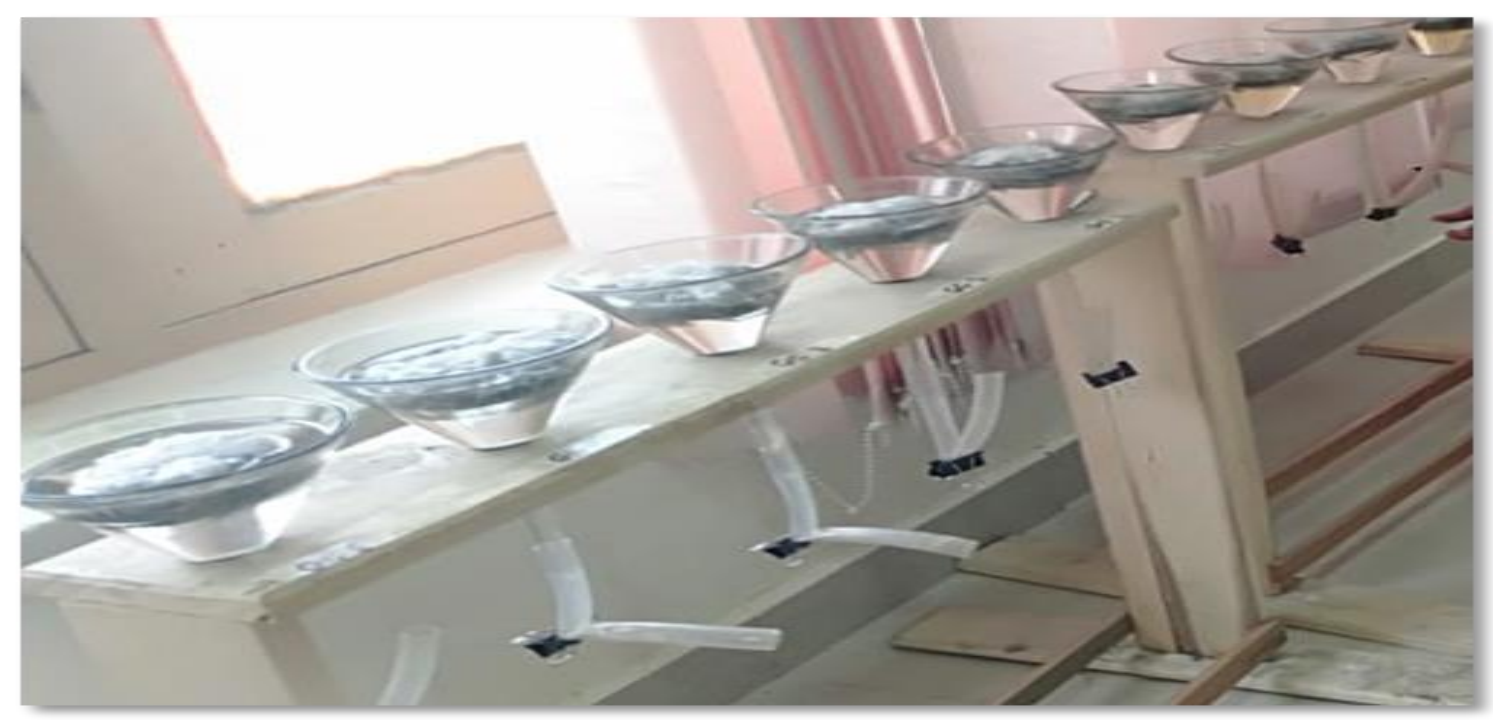

Figure 1. Baermann funnel method for extraction of nematodes 


\section{Soil physicochemical properties}

Soil texture was determined using hydrometer whereas the soil moisture was recorded gravimetrically for $48 \mathrm{~h}$ at 105 ${ }^{\circ} \mathrm{C}$. For measurement of electrical conductivity (EC) soil: water slurry in the ratio of 1:3 was prepared. For the determination of soil bulk density, corer method was used [17, 18]. Soil $\mathrm{pH}$ was analyzed using a digital $\mathrm{pH}$ meter while elevations and position were determined using GPS [19].

\section{Statistical analysis}

For statistical analysis software, SPSS 22.0 version was used [20]. The variables between the sites were compared using one-way ANOVA. The correlation between the soil physicochemical properties and nematodes density was measured using Pearsons Correlation Matrix.

\section{Result}

\section{Soil physicochemical properties and nematode density}

The five sites selected from potato fields and pine forests represented an elevation gradient (3000 to 3500) but the sites also varied concerning minerals, alluvial influences as well as slopes. Despite these potentially confounding factors, soils in plains have improved quality and are cultivated for vegetable crops including potatoes. Potato fields are located at less elevated areas as compared to pine forests. Moreover, the soil temperature, bulk density, sand and clay percent, EC, $\mathrm{pH}$ Soil moisture content increased in the potato fields as compared to pine forests (Table 1). However, percent silt was significantly higher in the pine forests than the potato fields. Higher $\mathrm{pH}$ indicates higher acidity in the potato field than the pine forests (Table 1). The nematode density varied significantly between the potato fields and pine forests. Soils from the potato fields have higher densities of nematodes than the pine forests. Nematode density across the samples from 5 to 397
$0.5 \mathrm{~kg}^{-1}$ per soil. Among the physicochemical properties, EC, $\mathrm{pH}$, nematode density and silt were significantly different between the potato field and pine forests. According to previous research, the $\mathrm{pH}$ of the soil decreases with the increase in elevation and is connected to soil moisture and organic matters which are deciding factors for the soil $\mathrm{pH}$ to become acidic or basic. Similarly, the electrical conductivity, is a measure of salinity, vary significantly and the salinity in the potato fields was significantly higher than the pine forests. Probably the location of potato fields is alluvial and likely experiences salt deposition.

\section{Trophic mode of nematodes}

The most abundant nematodes across all samples of potato fields and pine forests were bacterivores and fungivores followed by herbivores and omnivores (Fig. 2). The predators made a very small contribution to the communities and were barely detected. This may be because of the harsh environmental conditions of the area; the predators might not survive for a long time in this harsh environmental condition. Among these nematodes, bacterivores, herbivores and omnivores were significantly different between potato fields and pine forests. The bacteria feeding nematodes species generally were the most abundant across the sites, ranging from $31-81 \%$ of the nematodes found in each sample. The percentage of fungal feeding species were was almost similar in both potato fields and pine forests soils. The presence of fungal species in pine forests suggests that fungal feeding nematodes can flourish well even in under extreme conditions relative to bacteria feeding nematodes. Potato fields have significantly high bacterivores while the pine forest has high omnivores and herbivores. However, predators were barely detectable in both potato fields and pine forests (Fig. 2). 
Table 1. Soil properties and nematode density for GAPA valley

\begin{tabular}{|c|c|c|c|c|c|c|c|c|c|c|c|}
\hline Sites & *Alt(m) & $\mathbf{S T}\left({ }^{\circ} \mathrm{C}\right)$ & $\begin{array}{c}\text { BD }^{*} \\
(\mathrm{~g} / \mathrm{cm} 3)\end{array}$ & pH & $\mathbf{E C} *(\mu S)$ & Silt (\%) & Sand $(\%)$ & $\begin{array}{c}\text { Clay } \\
(\%)\end{array}$ & $\begin{array}{c}\text { SMC } \\
(\%)\end{array}$ & $\begin{array}{c}\text { ND }(0.5 K g \\
\text { per soil) }\end{array}$ & ST \\
\hline Potato field 1 & 3268 & 19.1 & 0.78 & 6.11 & 328 & 51.96 & 24.04 & 24 & 33.1 & 235 & Silty loam \\
\hline Potato field 2 & 3231 & 23.8 & 0.93 & 6.35 & 2100 & 60.02 & 19.98 & 20 & 24.09 & 5 & Sandy Loam \\
\hline Potato field 3 & 3218 & 21.1 & 0.78 & 6.49 & 1260 & 46.6 & 33.04 & 20 & 21.52 & 70 & Sandy Loam \\
\hline Potato field 4 & 3193 & 20 & 0.84 & 6.63 & 2250 & 31.1 & 50.9 & 18 & 17.93 & 397 & Silty Loam \\
\hline Potato field 5 & 3176 & 20.2 & 1.02 & 7.1 & 785 & 14.44 & 65.56 & 20 & 15.05 & 75 & Sandy Loam \\
\hline pine forest 1 & 3297 & 22.6 & 0.61 & 6.46 & 231 & 60.48 & 20.52 & 19 & 12.91 & 35 & Silty \\
\hline pine forest 2 & 3318 & 18.4 & 1.05 & 5.73 & 479 & 46.92 & 35.08 & 18 & 46.47 & 57 & Silty \\
\hline pine forest 3 & 3281 & 24.4 & 0.69 & 5.7 & 244 & 57.82 & 24.18 & 18 & 8.19 & 59 & Silty \\
\hline pine forest 4 & 3257 & 17.9 & 0.88 & 5.35 & 128.1 & 57.26 & 22.74 & 20 & 3.43 & 24 & Silty loam \\
\hline pine forest 5 & 3210 & 16.9 & 1.38 & 6.27 & 932 & 25.92 & 54.08 & 20 & 20.35 & 18 & Silty \\
\hline \multicolumn{12}{|l|}{ Averages ${ }^{1}$} \\
\hline Potato fields & $3217.2 \mathrm{a}$ & $20.84 a$ & $0.922 \mathrm{a}$ & $6.5 \mathrm{a}$ & $1344.6 \mathrm{a}$ & $40.82 \mathrm{a}$ & $38.704 a$ & $20.4 \mathrm{a}$ & $22.33 \mathrm{a}$ & $156.4 \mathrm{a}$ & Silty and Sandy loamy \\
\hline Pine forests & $3272.6 \mathrm{a}$ & $20.04 a$ & $0.87 \mathrm{a}$ & $5.9 \mathrm{~b}$ & $402.82 b$ & $49.68 b$ & $31.32 \mathrm{a}$ & $19 \mathrm{a}$ & $18.27 \mathrm{a}$ & $38.6 \mathrm{~b}$ & Silty \\
\hline
\end{tabular}

${ }^{1}$ Different letters along the columns indicate significant difference-based LSD test. *Alt (Altitude), ST (Soil Temperature), BD (Bulk density), EC (Electrical conductivity), SMC (Soil moisture contents), ND (Nematode density), ST(Soil texture) 


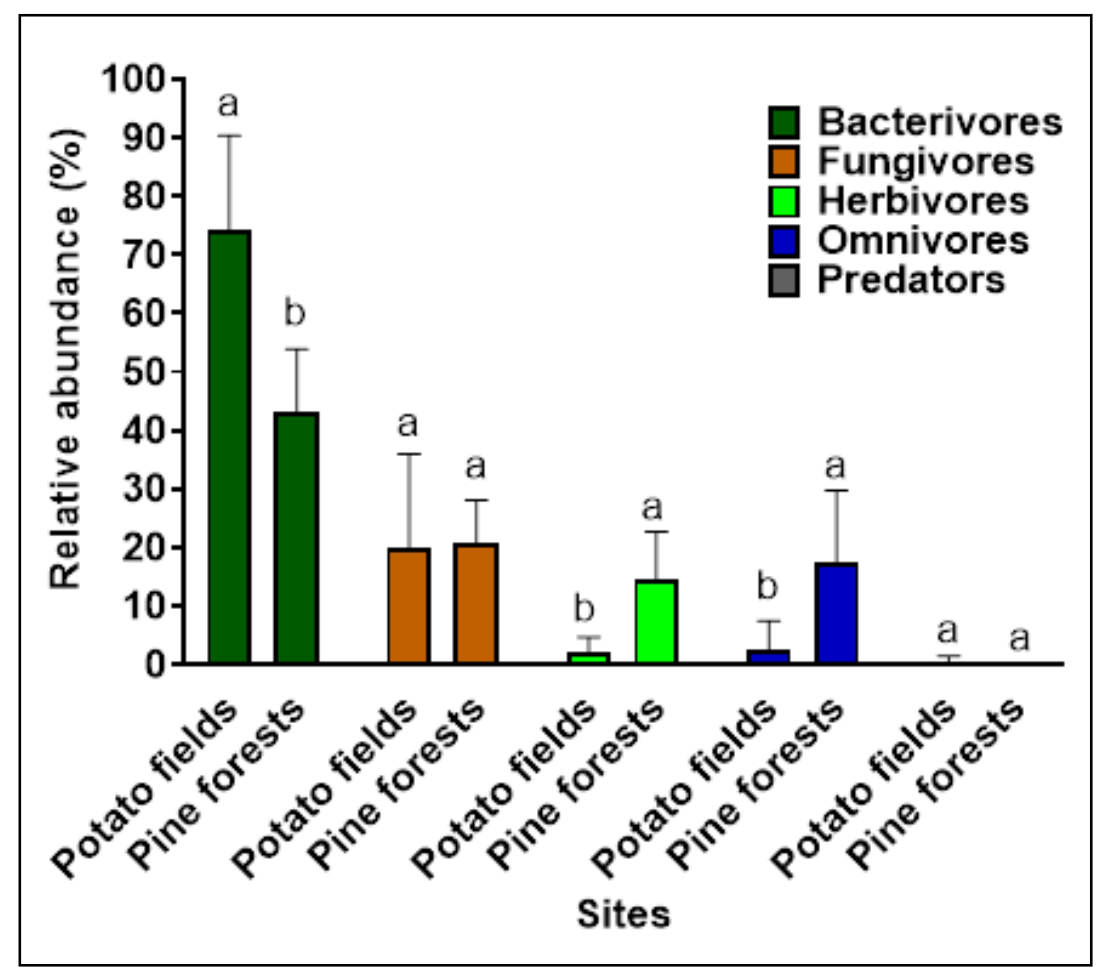

Figure 2. Nematode communities in soils from GAPA valley. The relative proportion of trophic groups in the communities. Values represent means \pm the standard error of the mean $(\mathrm{n}=5)$. The bars with different letters are significantly different (ANOVA, $P \leq$ 0.05, LSD)

Correlation between nematode density and physicochemical properties

Most of the physicochemical properties were negatively correlated. However, we found a significant positive correlation between soil moisture contents and nematode density both in potato fields and pine forests soils of GAPA valleys(Table 2 \& 3). However, in the potato fields, EC and sand $(\%)$ were positively correlated with the nematode density but in the pine forests EC was negatively correlated and instead of sand (\%), silt was positively correlated with the nematode density. Briefly, we were unable to establish a relationship between nematode density and physicochemical properties because most of the physiochemical properties were negatively correlated with nematode density (Table $2 \& 3$ ).

Table 2. Correlation between physicochemical properties of potato fields soil and nematode communities

\begin{tabular}{|c|c|}
\hline Physicochemical property & Nematode Density (ND) \\
\hline Soil temperature & -.661 \\
\hline Bulk density & -.432 \\
\hline $\mathrm{pH}$ & -.105 \\
\hline Electrical conductivity & $.145^{*}$ \\
\hline Soil moisture content & .042 \\
\hline Silt & -.236 \\
\hline Sand & $.240^{*}$ \\
\hline Clay & -.120 \\
\hline
\end{tabular}

* Values are for correlation analyses $(n=45 ; *$ Correlation was positive) 
Table 3. Correlation between physicochemical properties of pine forests soil and nematode communities

\begin{tabular}{|c|c|}
\hline Physicochemical property & Nematode Density (ND) \\
\hline Soil temperature & $.594^{*}$ \\
\hline Bulk density & -.437 \\
\hline $\mathrm{pH}$ & -.259 \\
\hline Electrical conductivity & -.335 \\
\hline Soil moisture content & $.398^{*}$ \\
\hline Silt & $.426^{*}$ \\
\hline Sand &.- .366 \\
\hline Clay & -.987 \\
\hline
\end{tabular}

* Values are for correlation analyses $(n=45 ; *$ Correlation was positive

\section{Discussion}

Soil contains complex soil biota and to determine the structure of these soil biota become difficult particularly in those regions where there are harsh environmental conditions. Our area of study was located at high elevation and there we investigated the nematode density and physicochemical properties of potatoes fields and pine forests. The physiochemical properties have varied in both potato fields and pine forests. We also investigated which soil of these two sites contains more nematode density and then correlated the nematode density with the physiochemical properties. Our results suggest that most of the physiochemical properties of the potato field and pine forests soils are negatively correlated with the population density of the nematodes. This study was in contrast to previous studies where most of the physiochemical properties were positively correlated with the nematode density. However, soil moisture contents were positively correlated with the nematode density. These results were in agreement with the studies conducted by [21], who found a significant positive correlation between electrical conductivity and nematode but not with soil moisture contents. The soils we sampled from potato fields are likely being irrigated from the nearby rivers and pine forests receive a high amount of rainfall during the whole year. The high moisture is playing important role in the establishment of higher density nematode communities. Similarly, potatoes are grown in sandy type soil in these valleys; the sandy soil was positively correlated with the nematode density however in the forest nematode density was positively correlated with the silt.

The nematode density is likely influenced by the diversity and abundance of food sources. More food is easily available more would be the population density [22]. Among the nematode's bacterivores and fungivores were dominant across the samples of both potato fields soils and pine forest soils and this is in agreement with the studies conducted by [21]. Moreover, bacterivores, omnivores and herbivores nematodes were found abundant in the potato fields as compared to pine forest. This result can be connected to the presence of more soil moisture in the potato fields as compared to pine forest because potato fields are regularly irrigated using nearby rivers water. The increase in free bacterivores, herbivores and omnivores nematodes in potato field can also be attributed to food availability. The potato fields are regularly given synthetic fertilizers as well as organic farmyard manures. The application of fertilizers and manures stimulated the nematode population; improve physical properties as well as fertility, and retained water, increase aeration and plant growth. Development of populations of soil microorganisms and reduce plant-parasitic nematode populations $[7,10]$. Therefore, a significant increase in the nematode 
density was noted in the potato fields. However, the population density of fungivores was almost similar in both pine forest and potato fields soils. These fungivores have an anhydrobiotic strategy that allowed nematodes to survive even in desiccating conditions in an ametabolic state $[7,8,23]$. The previous study showed that nematode density declined with the declined elevation and soil moisture contents [24]. But in Antarctic dry valleys, more diversity was recorded at lowest elevation sites and the highest elevation, the diversity of nematodes decreased [25]. There is a contrast between these studies and our studies, and our results suggest that rather than individual physicochemical properties affecting the structure of nematodes communities, the sites specific factors are playing a major role in structuring the nematode communities.

\section{Conclusion}

Most of the physicochemical properties were higher in the potato fields as compared to pine forests. More nematode density was recorded in the potato fields. Among the nematodes, bacterivores were significantly higher in the potato fields however omnivores and herbivores were abundant in the pine forests. Most of the physiochemical properties were negatively correlated with the nematode density except soil moisture contents of both potato fields and pine forests soils. Hence, we fail to support that there is a positive relationship between the nematode diversity of these regions and soil physicochemical properties. In future more research is needed to explore not only freeliving nematode but also the plant-parasitic nematode and then there is need to establish a relationship among the growth of pine forests, agriculture fields and diversity of these nematodes. Moreover, we also recommend molecular studies, which would be helpful to identify nematodes to species level.

\section{Authors' contributions}

Performed lab and field experiments and wrote the initial draft: M Shoaib, Supervised the research and provided facilities: S Mumtaz, Thoroughly read the manuscript, discussed the results and critically reviewed the manuscript: A Abbas, Provided research equipment for this research: F Begum, Checked physicochemical analysis: B Hussain.

\section{Acknowledgements}

The support of the Karakoram International University (KIU), Gilgit Baltistan, Pakistan are gratefully acknowledged. The authors are also grateful for the assistance of local farmers and people during the research. During the research, no animals or public property has been harmed or damaged.

\section{References}

1. Hartemink AE (2016). Chapter TwoThe definition of soil since the early 1800s. Advances in Agronomy, Sparks, DL, Ed Academic Press 137: 73-126.

2. Schoonover JE \& Crim JF (2015). An Introduction to Soil Concepts and the Role of Soils in Watershed Management. J of Contemp Water Res \& Edu 154: 21-47.

3. Egli M, Hunt AG, Dahms D, Raab G, Derungs C, Raimondi S \& Yu F (2018). Prediction of Soil Formation as a Function of Age Using the Percolation Theory Approach. Frontiers in Environ Sci 6.

4. Certini G (2014). Fire as a soil-forming factor. Ambio 43: 191-195.

5. Van Breemen N (2004). Chapter 2 The formation of soils. In Developments in Soil Sci, Doelman, P, Eijsackers, HJP, Eds. Elsevier 29: 21-40.

6. Ferris H (2010). Contribution of nematodes to the structure and function of the soil food web. J Nematol 42: 6367.

7. Gebremikael MT, Steel H, Buchan D, Bert W \& De Neve S (2016). Nematodes enhance plant growth and nutrient uptake under $\mathrm{C}$ and $\mathrm{N}$-rich conditions. Sci Rep 6: 32862-32862. 
8. Neher DA (2010). Ecology of Plant and Free-Living Nematodes in Natural and Agricultural Soil. Annual Rev of Phytopathol 48: 371-394.

9. Smythe AB, Holovachov O \& Kocot KM (2019). Improved phylogenomic sampling of free-living nematodes enhances resolution of higher-level nematode phylogeny. BMC Evolu Biol 19: 121.

10. Renčo M \& Kováčik P (2012). Response of plant parasitic and free living soil nematodes to composted animal manure soil amendments. $J$ Nematol 44: 329-336.

11. Vanreusel A, De Groote A, Gollner S \& Bright M (2010). Ecology and Biogeography of Free-Living Nematodes Associated with Chemosynthetic Environments in the Deep Sea: A Review. PLOS ONE 5: e12449.

12. Tchesunov AV (2015). Free-living nematode species (Nematoda) dwelling in hydrothermal sites of the North MidAtlantic Ridge. Helgoland Marine Res 69: 343-384.

13. Otranto D \& Deplazes P (2019) Zoonotic nematodes of wild carnivores. Inter J for Parasitology: Parasites and Wildlife 9: 370-383.

14. da Silva JVCdL, Hirschfeld MNC, Cares JE \& Esteves AM (2020). Land use, soil properties and climate variables influence the nematode communities in the Caatinga dry forest. Appl Soil Ecol 150: 103474.

15. Chhetri B \& Subedi JR (2019). Nematodes Associated with Kiwi Plants in Central Horticulture Centre Kirtipur, Kathmandu, Nepal. Int J Appl Agri Sci 5: 71-74.

16. Bongers $T$ (1988). De nematoden van Nederland: een identificatietabel voor de in Nederland aangetroffen zoetwateren bodembewonende nematoden; Koninklijke Nederlandse
Natuurhistorische Vereniging Zeist, The Netherlands.

17. Heuscher SA, Brandt CC \& Jardine PM (2005). Using Soil Physical and Chemical Properties to Estimate Bulk Density. Soil Sci Soc of Am J 69: 51-56.

18. Manrique LA \& Jones CA (1991). Bulk Density of Soils in Relation to Soil Physical and Chemical Properties. Soil Sci Soc of Am J 55: 476-481.

19. Mousavifard SM, Momtaz H, Sepehr E, Davatgar N \& Sadaghiani MHR (2013). Determining and mapping some soil physico-chemical properties using geostatistical and GIS techniques in the Naqade region, Iran. Archives of Agro and Soil Sci 59: 1573-1589.

20. IBM Corp N (2013). IBM SPSS statistics for windows. (Version 22.0).

21. Treonis A, Sutton K, Kavanaugh B, Narla A, McLlarky T, Felder J, O'Leary C, Riley M, Pikus A \& Thomas S (2012). Soil nematodes and their prokaryotic prey along an elevation gradient in the Mojave Desert (Death Valley National Park, California, USA). Diversity 4: 363-374.

22. Behmer ST \& Joern A (2008). Coexisting generalist herbivores occupy unique nutritional feeding niches. Proceedings of the National Acad of Sci 105: 1977-1982.

23. Crowe JH, Hoekstra FA \& Crowe LM (1992). Anhydrobiosis. Annual Rev of Physiol 54: 579-599.

24. Steinberger $Y$, Liang W, Savkina E, Meshi T \& Barness G (2001). Nematode community composition and diversity associated with a topoclimatic transect in a rain shadow desert. Euro $J$ of Soil Biol 37: 315-320.

25. Powers LE, Ho M, Freckman DW \& Virginia RA (1998). Distribution, community structure, and microhabitats of soil invertebrates along an elevational gradient in Taylor Valley, Antarctica. Arctic and Alpine Res 30: 133-141. 